\title{
Suppression of Endotoxin-Induced Renal Tumor Necrosis Factor- $\alpha$ and Interleukin-6 mRNA by Renin-Angiotensin System Inhibitors
}

\author{
Ryo Niimi, Akio Nakamura* and Yukishige Yanagawa \\ Department of Paediatrics, Teikyo University School of Medicine, 2-11-1 Kaga, Itabashi-ku, Tokyo 173-8605, Japan
}

Received June 25, 2001 Accepted October 31, 2001

\begin{abstract}
The present study was designed to clarify the role of angiotensin II (Ang II) in modulating renal tumor necrosis factor (TNF)- $\alpha$ and interleukin-6 (IL-6) production and to investigate the effect of one dose of Ang II inhibitor on cytokines production following lipopolysaccharide (LPS) to cause endotoxemia. Two studies were performed: 1) Ang II was infused intravenously at a rate of $0.2 \mu \mathrm{g} / \mathrm{kg}$ per minute for $4 \mathrm{~h}$ in rats and then kidneys were collected to assay TNF- $\alpha$ and IL-6 mRNA levels; 2) Four-week-old Wistar rats pre-treated with angiotensin-converting enzyme inhibitor, enalapril, or type I Ang II-receptor antagonist, TCV-116, were injected with LPS $(0.1,0.5,1.0 \mathrm{mg}$, i.p.), and then 2 or $4 \mathrm{~h}$ later, kidneys were collected to assay TNF- $\alpha$, IL-6, renin and angiotensinogen mRNA levels. After a 4-h intravenous infusion of Ang II, renal TNF- $\alpha$ or IL-6 mRNA level significantly increased 1.9-fold or 2.1 -fold (each $P<0.05$ ) to the control level, respectively. LPS stimulated TNF- $\alpha$, IL- 6 and angiotensinogen mRNA levels in the kidney but in rats given enalapril or TCV-116, LPS-induced IL-6 and TNF- $\alpha$ mRNA levels were completely suppressed (each $P<0.05$ ). This suggests that a single dose of renin-angiotensin system inhibitor suppressed renal IL-6 and TNF- $\alpha$ production and may prevent cytokine-induced renal damage during endotoxemia.
\end{abstract}

Keywords: Tumor necrosis factor- $\alpha$, Interleukin-6, Angiotensin II, Kidney, Lipopolysaccharide

Endotoxemia caused by gram-negative bacteria can result in sepsis and organ dysfunction, including kidney damage and renal failure $(1,2)$. The pathological mechanisms responsible for this renal dysfunction involve several mediators, cytokines, angiotensin II (Ang II), nitric oxide and catecholamines $(3,4)$. The cytokines produced from activated macrophages play an important role in the production of nitric oxide which exhibits cytotoxic properties. Especially, tumor necrosis factor (TNF) is a primary inducer in endotoxemia and is regarded as a central mediator of the pathophysiological changes associated with lipopolysaccharide (LPS) (5). Interleukin-6 (IL-6) is also involved in mediating various components of the immune and inflammatory responses $(6-8)$. Therefore, the possibility arises that renal TNF- $\alpha$ and IL- 6 generation is involved with the endotoxemia-induced deterioration in renal function. Indeed, Fouqueray et al. (9) demonstrated that TNF- $\alpha$ and IL-6 were produced promptly by isolated glomeruli after in vivo or in vitro exposure to LPS, suggesting an important role of these cytokines in the development of endotoxininduced renal dysfunction. In order to protect the kidney

*Corresponding author. FAX: +81-3-3579-8212

E-mail: akio@med.teikyo-u.ac.jp from damage during endotoxemia, it is necessary to understand the factors that contribute to the regulation of renal TNF- $\alpha$ and IL- 6 production induced by endotoxin.

Ang II plays a role and may be involved in determining the release and gene expression of TNF- $\alpha$ and IL- 6 from the kidney. Moriyama et al. (10) and our own study (11) documented that Ang II caused IL-6 release and gene expression in cultured mesangial cells and in renal resident macrophage cells. Kaneto et al. (12) demonstrated that the elevation in TNF- $\alpha$ mRNA levels after ureteral obstruction was decreased following Ang II inhibition, which suggested that Ang II was involved in the increased expression of TNF- $\alpha$ mRNA in the obstructed kidney (12). Because Ang II is released during endotoxemia (3), it may have the potential of contributing to the development of endotoxemia-induced renal damage as a consequence of elevated TNF- $\alpha$ and IL- 6 production. However, whether Ang II regulates the generation of LPS-induced TNF- $\alpha$ and IL-6 remains unclear. If the stimulatory effects of endotoxin on renal TNF- $\alpha$ and IL- 6 can be modulated by renal Ang II, there may be a possibility that administration of reninangiotensin system (RAS) inhibitor, such as angiotensinconverting enzyme (ACE) inhibitor or a type I Ang II (AT1) receptor antagonist, could act as a safeguard in 
preventing cytokine-induced renal damage during endotoxemia.

The objective of the present study was to clarify whether, in vivo, Ang II stimulates renal TNF- $\alpha$ and IL-6 productions and how these cytokines may be modulated by a single dose of RAS inhibitor during an endotoxemic challenge. The findings of the study provided evidence that administration of one dose of an ACE inhibitor or a AT1-receptor antagonist suppressed renal TNF- $\alpha$ and IL-6 mRNA levels in rats following LPS injection.

\section{MATERIALS AND METHODS}

\section{Reagents}

ISOGEN was obtained from Nippon Gene (Tokyo). The Multiprime DNA labelling system and [alpha- $\left.{ }^{32} \mathrm{P}\right] \mathrm{dCTP}$ were purchased from Amersham International PLC (Little Chalfont, UK). Biodyne A membranes were obtained from Pall Ultrafine Filtration (Glen Cove, NY, USA). The RT RNase H-reverse Transcriptase kit was obtained from Super Script, Bethesda Research Laboratories (Gaithersburg, MD, USA). The fluorescence imaging analyzer (FluorImager SI) was made by Molecular Dynamics-Japan (Tokyo). CS9200 was made by Shimadzu Co., Ltd. (Kyoto). BAS III and BAS 2000 were from Fuji Photo Film Co., Ltd. (Tokyo). Enalapril was a gift from Banyu Pharm. Corp. (Tokyo), and TCV-116 was a gift from Takeda Chemical Industries, Ltd. (Osaka). Unless stated, other reagents were obtained from Sigma Chemical Co. (St. Louis, MO, USA).

\section{Rat preparation and protocols}

The animal experimentation was conducted in accord with the Teikyo University Guide for the Care and Use of Laboratory Animals. The rats were fed a standard laboratory diet (126 mEq of $\mathrm{Na} / \mathrm{kg}$ and $118 \mathrm{mEq}$ of $\mathrm{K} / \mathrm{kg}$ food) and had free access to water.

In vivo study I: The experiments were performed on 8 male Wistar rats that were 5-6-week old and weighed $150-170 \mathrm{~g}$. On the day of the study, under light pentobarbital anesthesia (50 mg/kg, i.p.), polyethylene catheters (PE-50) were placed in the femoral vein. An infusion of saline was begun at $3 \mathrm{ml} / \mathrm{h}$ and continued at the same rate throughout the experiment. On completion of all surgery, saline infusion was changed to one containing pentobarbital such that it was delivered at $12 \mathrm{mg} / \mathrm{kg}$ per hour. The experiment was performed $2.5 \mathrm{~h}$ later once stable levels of cardiovascular and renal function had been achieved. Ang II was infused intravenously at a rate of $0.2 \mu \mathrm{g} / \mathrm{kg}$ per minute for $4 \mathrm{~h}$ in 4 rats. The dose of Ang II increased mean blood pressure by $57 \mathrm{mmHg}$ (13). Saline solution alone was infused in four other rats as a control. All rats were sacrificed using intravenous injection of pentobarbital in order to measure TNF- $\alpha$ and IL- 6 mRNA levels.
In vivo study II: Four-week-old Wistar rats $(100-120 \mathrm{~g})$ were divided into 4 groups and subjected to the following regimes: Group I $(\mathrm{n}=4)$ and II $(\mathrm{n}=4)$ rats drank distilled water; Group III $(n=4)$ or IV $(n=4)$ rats was given a single dose of ACE inhibitor (enalapril, $10 \mathrm{mg} / \mathrm{kg}$, p.o.) or AT1receptor antagonist (TCV-116, $10 \mathrm{mg} / \mathrm{kg}$, p.o.), respectively. Twenty minutes later, LPS (Escherichia coli O127:B8, $1 \mathrm{mg}$, i.p.) was injected to rats of Groups II-IV and Group I rats were not given LPS as a control. Two and four hours later, kidneys were taken in order to measure TNF- $\alpha$, IL-6, renin and angiotensinogen mRNA levels. In addition, to evaluate the dose-response effects of LPS on TNF- $\alpha$ and IL-6 mRNA in the kidney, LPS $(0.1$ or $0.5 \mathrm{mg})$ was injected intraperitoneally to other Wistar rats (each $n=3)$.

\section{RNA analysis}

We estimated mRNA levels using Northern blot hybridization analysis as described in our previous study (13) and a previously described semi-quantitative PCR technique (14). Briefly, total RNA was extracted from the whole left kidney using ISOGEN according to the manufacturer's instructions. For Northern blot hybridization, the 600 base-pairs Eco RI/Hind III fragment derived from the cDNA insert of clone pGEM (15) for murine IL-6, the 698-base pairs Kpn I fragment for rat renin (16), the 712base pair Bam HI fragment derived from the cDNA insert of clone pRag16 for rat angiotensinogen (17), or the 420 base-pairs Hinf I fragment for human $\beta$-actin (National Children's Research Centre, Tokyo) was used as a cDNA probe for IL-6, renin, angiotensinogen or $\beta$-actin, respectively. The cDNA for TNF- $\alpha$ was constructed by the reverse transcription (RT)-PCR product (546 bp) using RNA isolated from rat kidney (18). These cDNA probes were labelled by the oligolabelling method in the presence of $\left[\right.$ alpha- $\left.{ }^{32} \mathrm{P}\right] \mathrm{dCTP}$ and used as a hybridization probe. All mRNA samples $(20 \mu \mathrm{g})$ were applied to a Biodyne A membrane, hybridized simultaneously and exposed for the same time. For TNF- $\alpha$ and IL-6 mRNA, the membranes were exposed on an imaging plate (BAS III) and the incorporated radioactivity was measured with a Bioimage analyzer (BAS 2000). The radioactivity was expressed as PSL (photostimulated luminescence) units and was used as an index of mRNA level. On the other hand, for renin and angiotensinogen mRNA, autoradiograms were prepared with an intensifying screen at $-80^{\circ} \mathrm{C}$ and were scanned with a densitometer (CS9200) to determine individual band densities. The data were expressed as the amount of TNF- $\alpha$, IL-6, renin and angiotensinogen mRNA over the amount of $\beta$-actin mRNA.

For PCR analysis, reverse transcription of $2 \mu \mathrm{g}$ of total RNA of the kidney was carried out with the RT RNase H-reverse Transcriptase kit, which was used for the synthesis of the first strand cDNA and subsequently subjected 
to amplification with the PCR for $\beta$-actin, IL- 6 and TNF- $\alpha$ primers. The following primers have been previously published (19) and were used for cytokine gene amplification:

TNF- $\alpha$ (sense) 5'-CACCACGCTCTTCTGTCTACTGAAC-3'

TNF- $\alpha$ (antisense) 5'-CCGGACTGCGTGATGTCTAAGTACT-3' IL-6 (sense) 5'- GACTGATGTTGTTGACAGCCAGTGC-3'

IL-6 (antisense) 5'-TAGCCACTCCTTCTGTGACTCTAACT-3'

$\beta$-actin (sense) 5'-TGGAATCCTGTGGCATCCATGAAAC-3'

$\beta$-actin (antisense) 5'-TAAAACGCAGCTCAGTAACAGTCCG-3'

To carry out the PCR, the tubes containing $50 \mu \mathrm{l}$ of the reaction mixture were placed in the programmed tempcontrol system set up as follows: 1) denaturing for $1 \mathrm{~min}$ at $95^{\circ} \mathrm{C}, 2$ ) annealing primers for $1 \mathrm{~min}$ at $60^{\circ} \mathrm{C}$ and 3 ) extending the primers for $1 \mathrm{~min}$ at $72^{\circ} \mathrm{C}$. The PCR technique employed 25 cycles of amplification in the analysis of $\beta$-actin and 30 cycles for IL- 6 and TNF- $\alpha$ to ensure that a linear relationship could be obtained between the PCR cycle number and cytokine cDNA as PCR product (20). A portion $(20 \mu \mathrm{l})$ of the PCR solution was electrophoresed in $2 \%$ agarose gel, stained with ethidium bromide and visualized with an ultraviolet transilluminator. Imaging and analysis of the PCR products separated by electrophoresis was performed using the fluorescence imaging analyzer (FluorImager SI). Images on the gels were scanned into the analyzer and the images of ethidium-bromide stained DNA fragments quantified using ImageQuaNT (Microsoft) software in the computer. Therefore, relative fluorescent units (rfu) were used as an index of mRNA level. RT-PCR of $\beta$-actin served as an internal control. The data were expressed as amount of cytokine product over the amount of $\beta$-actin product (cytokine/ $\beta$-actin ratio).

\section{Statistics}

Statistical analysis was performed by ANOVA followed by the Bonferroni's test for multiple comparisons. The Student's $t$-test was used to compare TNF- $\alpha$ or IL-6 mRNA levels in the in vivo study I. Results were expressed as the mean \pm S.E.M.

\section{RESULTS}

The effects of Ang II on TNF- $\alpha$ or IL-6 mRNA level in the kidney in the in vivo study I are shown in Fig. 1 in which TNF- $\alpha$ or IL-6 gene expression was analyzed using Northern blots. It was found that Ang II was able to stimulate renal TNF- $\alpha$ or IL-6 mRNA levels by 1.9 -fold or by 2.1-fold (each $P<0.05$ ), respectively. Intravenous infusion of Ang II for $4 \mathrm{~h}$ significantly increased TNF- $\alpha$ or IL-6 production in the kidney.

The effects of RAS inhibitors on LPS-induced TNF- $\alpha$ mRNA in the kidney in in vivo study II are shown in Fig. 2 in which TNF- $\alpha$ and IL-6 gene expression were analyzed using RT-PCR. In the rat kidney, TNF- $\alpha$ and IL- 6 gene expressions in the kidney were too low to be detected reliably using Northern blots. Therefore, the alternative approach was developed of using semi-quantitation of RT-PCR methodology to estimate the TNF- $\alpha$ and IL-6 mRNA in in vivo study II. Figure 2 shows that LPS $(0.1$, $0.5,1 \mathrm{mg}$ ) caused a dose- and time-dependent stimulation of renal TNF- $\alpha$ or IL- 6 mRNA level. Especially, LPS (Group II: $1 \mathrm{mg}$, i.p.) significantly up-regulated renal TNF- $\alpha$ or IL- 6 mRNA levels $4 \mathrm{~h}$ after the treatment by 2.8-fold or 3.3-fold (each $P<0.05$ ), respectively (Fig. 2: $\mathrm{B}$ and D). Furthermore, the addition of the ACE inhibitor (Group III: enalapril, p.o.) or an AT1-receptor antagonist (Group IV: TCV-116, p.o.) was able to suppress LPS ( $1 \mathrm{mg}$, i.p.)-induced renal TNF- $\alpha$ and IL- 6 mRNA levels (each $P<0.05$ ). A significant decrease in the kidney TNF- $\alpha$ mRNA induced by these RAS inhibitors occurred $4 \mathrm{~h}$ after the LPS challenge (Fig. 2: A and B), whereas a significant decrease in the kidney IL-6 mRNA occurred $2 \mathrm{~h}$ and $4 \mathrm{~h}$ after the treatment (Fig. 2: C and D).

The influence of the various treatments on the renal renin and angiotensinogen mRNA levels was measured at the same time in the in vivo study II (Fig. 3). Renin mRNA levels were not changed in rats subjected to LPS alone treatment (Group II). However, enalapril (Group III) and TCV-116 (Group IV) had a stimulatory effect on the LPSinduced renin mRNA levels in the kidney (Fig. 3: A and B). On the other hand, LPS $(0.1,0.5,1 \mathrm{mg})$ caused a dosedependent stimulation of renal angiotensinogen mRNA level. LPS (Group II: $1 \mathrm{mg}$, i.p.) significantly stimulated angiotensinogen mRNA in the kidney $2 \mathrm{~h}$ or $4 \mathrm{~h}$ after the treatment by 4.1 -fold or 4.0 -fold (each $P<0.05$ ), respectively (Fig. 3: C and D). Moreover, the addition of enalapril (Group III) or TCV-116 (Group IV) significantly decreased the LPS-induced angiotensinogen mRNA in the kidney $(P<0.05)$. The significant changes in renal renin and angiotensinogen mRNA levels induced by these RAS inhibitors occurred 2 and $4 \mathrm{~h}$ after the LPS challenge.

\section{DISCUSSION}

The present study shows that 1) Ang II influences renal TNF- $\alpha$ and IL-6 production and 2) administration of a single dose of the RAS inhibitors, such as the ACE inhibitor enalapril and the AT1-receptor antagonist TCV-116, down-regulates the LPS-induced renal TNF- $\alpha$ and IL-6 mRNA levels. The renal renin-angiotensin system, stimulated by endotoxin (21) and Ang II (22), could lead to a stimulation of renal TNF- $\alpha$ and IL-6 production $(10-12)$, which was suppressed following the addition of RAS inhibitors.

It was clear that in the in vivo study II, RAS inhibitors increased renin mRNA in the kidney, which was most likely a consequence of modulation of renal renin gene 

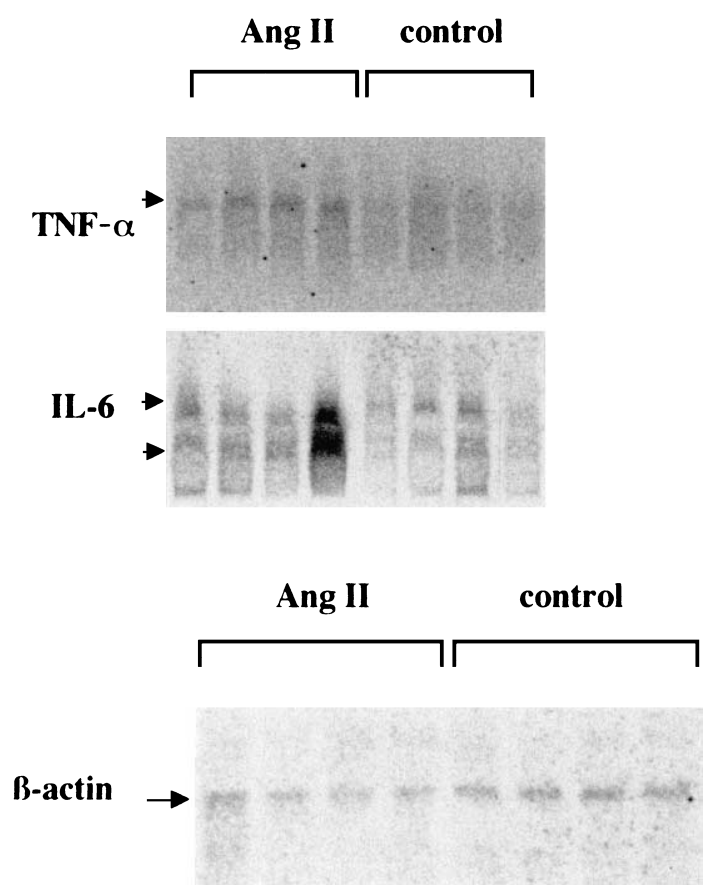
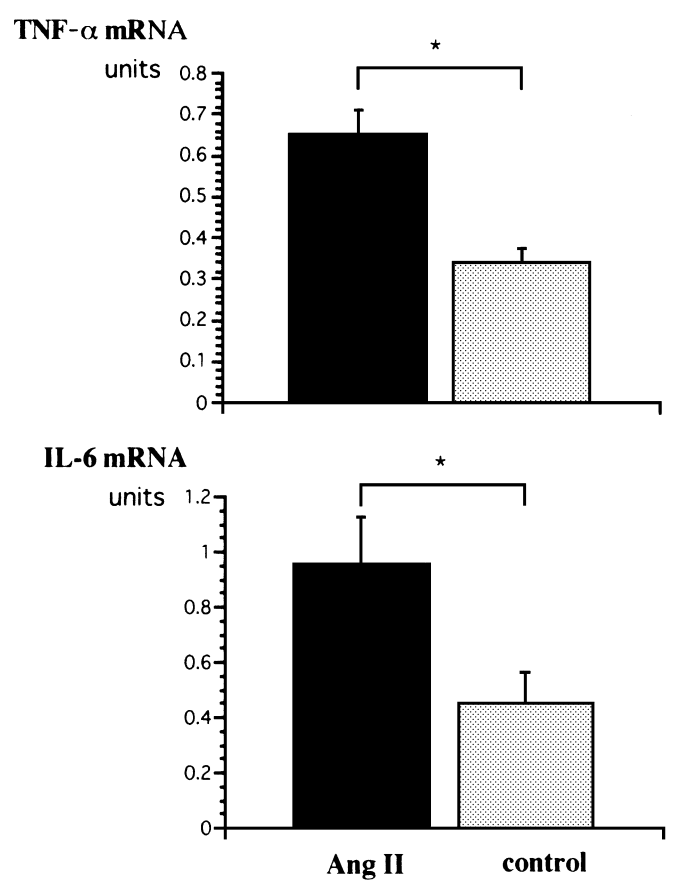

Fig. 1. Effects of Ang II infusion for $4 \mathrm{~h}$ on TNF- $\alpha$ and IL-6 mRNA levels in the kidney. Data of mRNA units in each group are the mean \pm S.E.M. from four rats and were expressed as the amount of TNF- $\alpha$ or IL- 6 mRNA over the amount of $\beta$-actin mRNA. Two forms of IL- 6 were evident, the $1.3-\mathrm{kb}$ band representing the most prominent form. Values were compared by Student's $t$-test. $* P<0.05$ vs control group.

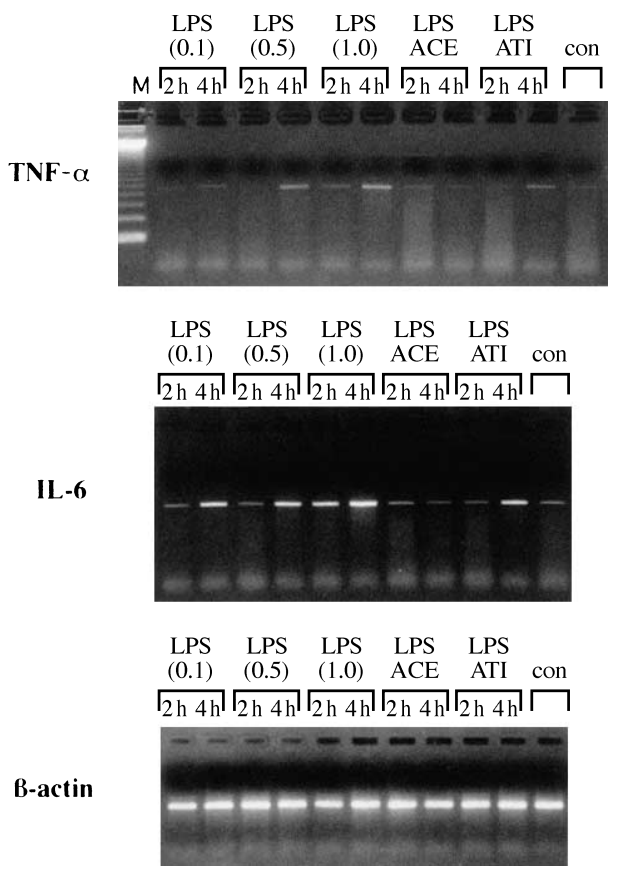

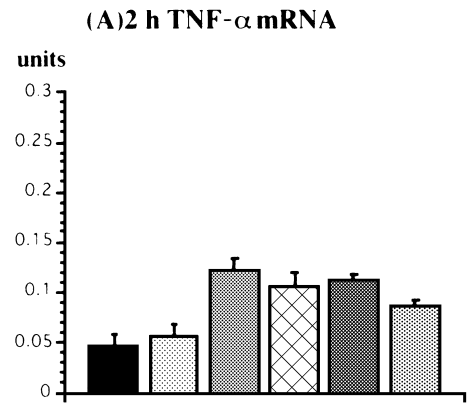

(C) 2 h IL-6 mRNA

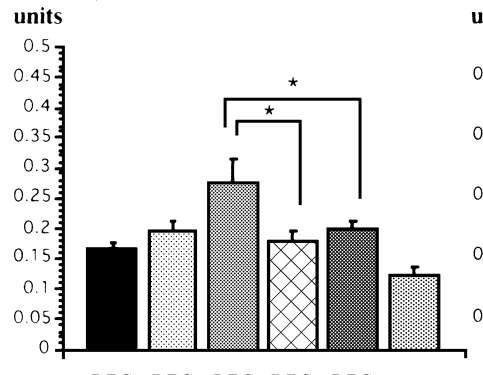
$\begin{array}{lllll}\text { LPS } & \text { LPS } & \text { LPS } & \text { LPS LPS } \\ (0.1) & (0.5) & (1.0) & \text { ACE } & \text { ATI }\end{array}$

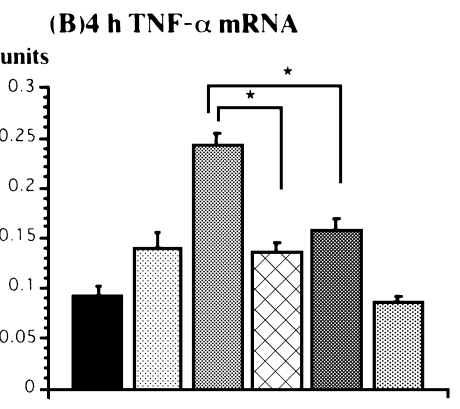

(D)4 h IL-6 mRNA

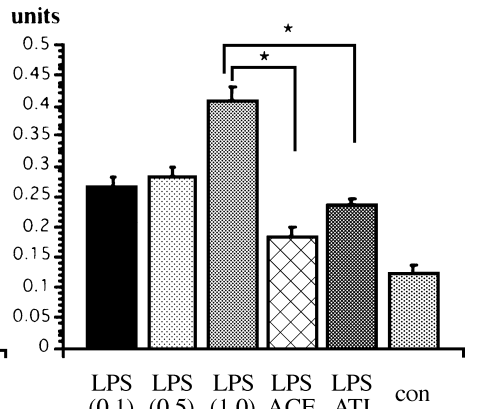

LPS LPS LPS LPS LPS con

Fig. 2. Effects of an ACE inhibitor or an AT1-receptor antagonist on LPS-induced TNF- $\alpha$ and IL-6 mRNA levels in the kidney. TNF- $\alpha$ and IL-6 mRNA levels $2 \mathrm{~h}$ (A and C) and $4 \mathrm{~h}$ (B and D) after the LPS challenge were measured using RT-PCR. LPS (0.1, $0.5,1.0)$ rats were injected intraperitoneally with $0.1,0.5$ or $1.0 \mathrm{mg}$ of LPS, respectively. LPS ACE or LPS AT1 rats were given by LPS (1 mg, i.p.) and a single dose of ACE inhibitor (enalapril, $10 \mathrm{mg} / \mathrm{kg}$, p.o.) or AT1-receptor antagonist (TCV-116, $10 \mathrm{mg}$ $/ \mathrm{kg}$, p.o.), respectively. The rats without any treatment were used as the control (con). Data of mRNA units in each group are the mean \pm S.E.M. from three to four rats and were expressed as the amount of TNF- $\alpha$ or IL- 6 mRNA over the amount of $\beta$-actin mRNA. Size marker (M) is a 123-bp ladder. Statistical analysis was performed by ANOVA followed by the Bonferroni's test. $* P<0.05$ vs LPS (1.0)-treated rats. 

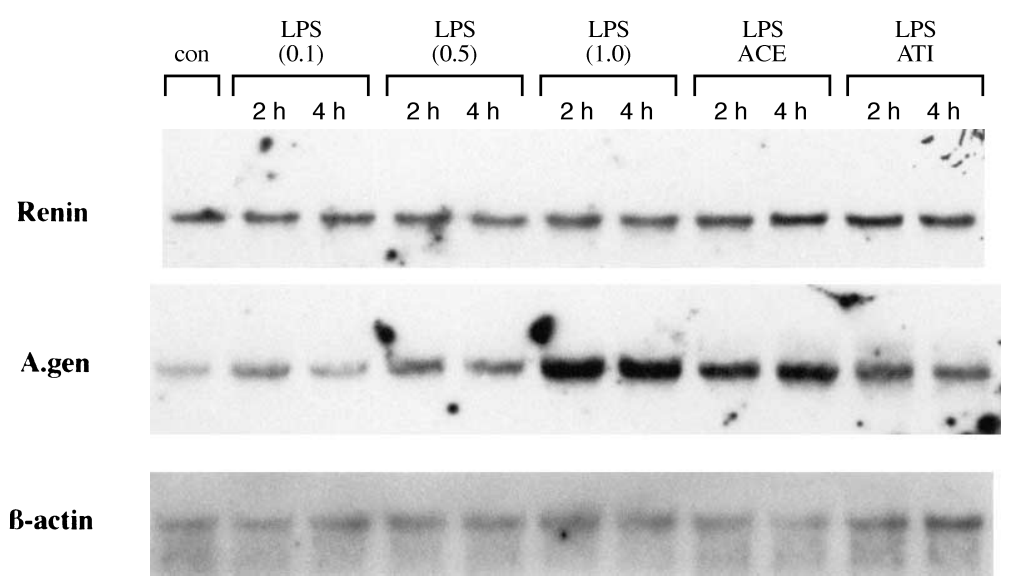

(A)2 h Renin mRNA
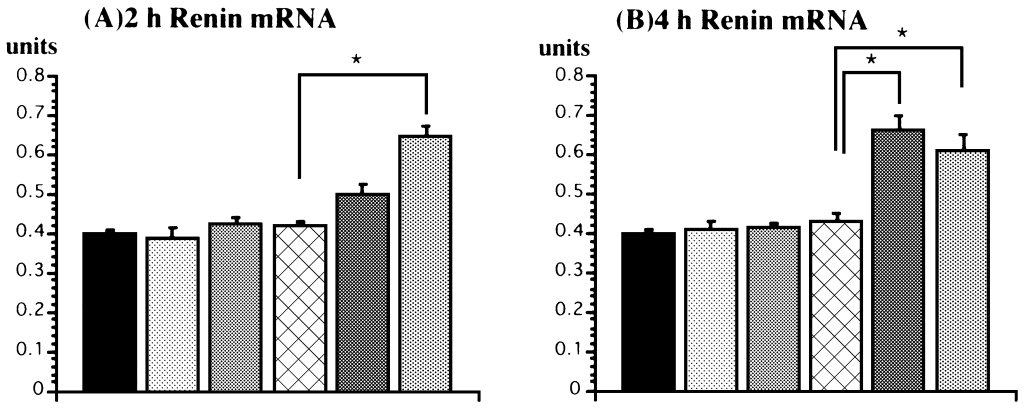

(C)2 h A.gen mRNA

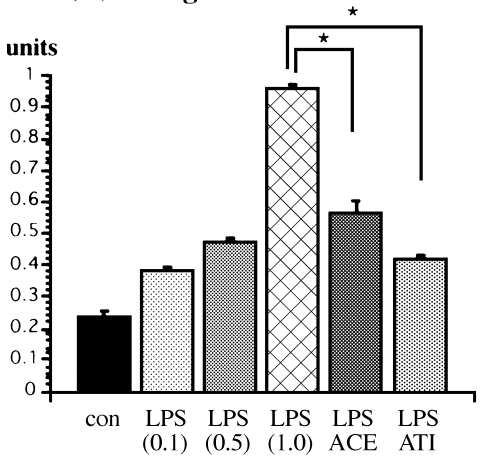

(D)4 h A.gen mRNA

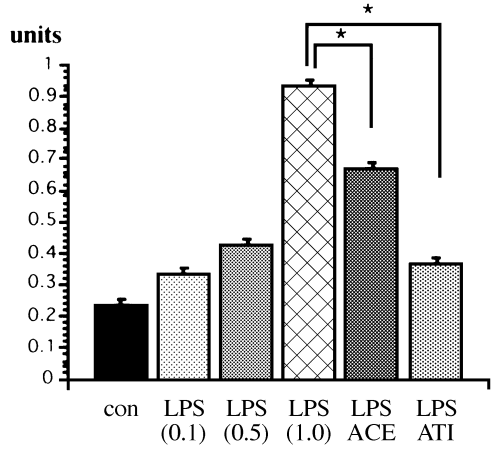

Fig. 3. Effects of LPS and/or RAS inhibitors on renin and angiotensinogen (A.gen) mRNA levels in the kidney. Renal renin and angiotensinogen mRNA levels $2 \mathrm{~h}(\mathrm{~A}$ and $\mathrm{C}$ ) and $4 \mathrm{~h}$ (B and D) after the LPS challenge were measured using Northern blots. LPS $(0.1,0.5,1.0)$ rats were injected intraperitoneally with $0.1,0.5$ or $1.0 \mathrm{mg}$ of LPS, respectively. LPS ACE or LPS AT1 rats were given LPS (1 mg, i.p.) and a single dose of ACE inhibitor (enalapril, $10 \mathrm{mg} / \mathrm{kg}$, p.o.) or AT1-receptor antagonist (TCV-116, $10 \mathrm{mg} / \mathrm{kg}$, p.o.), respectively. The rats without any treatment were used as the control (con). Data of mRNA units in each group are the mean \pm S.E.M. from three to four rats and were expressed as the amount of renal renin and angiotensinogen mRNA over the amount of $\beta$-actin mRNA. Statistical analysis was performed by ANOVA followed by the Bonferroni's test. ${ }^{*} P<0.05$ vs LPS (1.0)-treated rats.

expression by Ang II as we have shown previously (23). Angiotensinogen mRNA levels in the kidney were decreased by ACE inhibitors or AT1-receptor antagonists as has been reported previously $(24,25)$. The suppression of angiotensinogen mRNA following enalapril or TCV-116 treatment would suggest that renal angiotensinogen production is upregulated by Ang II. Kobori et al. (26) reported that increased angiotensinogen mRNA levels contribut- ed to the maintenance of intrarenal endogenous Ang II levels observed in Ang II-treated hypertensive rats. LPS stimulated renal angiotensinogen mRNA. Thus, these results suggested that LPS may be able to enhance the effect of renal Ang II, while the addition of enalapril (Group III) or TCV-116 (Group IV) may diminish the effect of Ang II induced by the LPS challenge.

Ang II has chemotactic properties (27), binds to macro- 
pharges, increases the macrophage-mediated oxidation of low-density lipoproteins (28) and induces platelet-derived growth factor in smooth muscle cells (29). At the level of the kidney, renal Ang II is a key factor in mediating various components of the immune and inflammatory responses (30). Therefore, it is possible that the renin-angiotensin system itself influences cytokine synthesis. This is supported by the in vivo study I showing that intravenous infusion of Ang II was able to increase TNF- $\alpha$ and IL-6 gene expression in the kidney. Because Ang II infusions significantly increased intrarenal Ang II content (22), the augmented intrarenal Ang II may stimulate renal TNF- $\alpha$ and IL-6 production $(10-12)$. One possible mechanism by which the Ang II-infused rats had increased renal TNF- $\alpha$ and IL-6 mRNA levels may be related to the augmented plasma Ang II levels. ACE inhibitors suppressed LPSinduced TNF- $\alpha$ levels in the plasma (31). Therefore, circulating RAS components may involve the regulation of plasma cytokines induced by LPS, which in turn suppressed TNF- $\alpha$ and IL- 6 in the kidney. The renin-angiotensin system can be activated by LPS and also produce TNF- $\alpha$ and IL-6, as has become evident from the findings of this study, which is compatible with the reports that renal TNF- $\alpha$ and IL- 6 increased in states of endotoxemia (32) and may be involved in inducing renal tissue damages $(6,33)$.

The important finding arising from the in vivo study II suggested that a single dose of RAS inhibitors had potent inhibitory effects on the LPS-stimulated TNF- $\alpha$ and IL-6 gene expression in the kidney. TCV-116 is able to antagonize the effects of Ang II by blockade of Ang II -binding to the macrophage receptors, and therefore may also exert anti-inflammatory effects (28). Enalapril inhibits Ang IIsynthesis from Ang I and may suppress pro-inflammatory cytokine production as has been shown in vitro previously (34). Thus, a single dose of enalapril or TCV-116 may be useful in the treatment of some patients with bacterial sepsis and could potentially offer protection from cytokinemediated change to the kidney. Peeters et al. (35) reported that administration of a single dose of ACE inhibitor or AT1 antagonist inhibited the LPS-stimulated production of TNF- $\alpha$ and IL-1 by peripheral blood mononuclear cells. However, they also indicated that these effects were exerted mainly at high concentrations, which could not be achieved in vivo. In the present study, the potential inhibitory effect of these RAS inhibitors on renal cytokines was observed in vivo. This suggests a possibility that administration of a single dose of RAS inhibitor in therapeutic dosages to humans with hypertension may suppress renal cytokines. In terms of renal function in in vivo study II, we did not measure blood pressure levels, glomerular filtration rate and renal blood flow before and after treatment with LPS and/or RAS inhibitors. Because LPS causes hypo- tension, blood pressure may be depressed furthermore by the addition of RAS inhibitors. However, all rats in group II - IV survived following LPS treatment. Further examination will be needed to assess whether the antiinflammatory effect of RAS inhibitors prevents the development of renal dysfunction following LPS injection.

\section{Acknowledgments}

The authors would like to thank Dr. Takao Kohsaka (National Children's Hospital, Tokyo) for his prompt and opportune help concerning the RNA analysis. This study was supported by grants from the Human Science Foundation in Japan.

\section{REFERENCES}

1 Zager RA: Escherichia coli endotoxin injections potentiate experimental ischemic renal injury. Am J Physiol 251, F988 F994 (1986)

2 Kikeri D, Pennel JP, Hwang KH, Jakob JI, Richman AV and Bourgigne JJ: Endotoxemic acute renal failure in awake rats. Am J Physiol 250, F1098 - F1106 (1986)

3 Schaller MD, Waeber B, Nussberger $\mathrm{J}$ and Brunner HR: Angiotensin II, vasopressin, and sympathetic activity in conscious rats with endotoxemia. Am J Physiol 249, H1086H1092 (1985)

4 Henrich W L, Hamasaki Y, Said SI, Campell WB and Cronin RE: Dissociation of systemic and renal effects in endotoxemia. J Clin Invest 69, 691 - 699 (1982)

5 Gluser MP, Zanetti G, Baumgartner J-D and Cohen J: Septic shock: pathogenesis. Lancet 338, 732 - 736 (1991)

6 Hirano $\mathrm{T}$ and Kishimoto T: Interleukin-6. In Handbook of Experimental Pharmacology, Vol 95/1, Edited by Sporn MB and Roberts AB, pp 633 - 665, Springer-Verlag, Berlin (1990)

7 Mantinaro V, Hevey K and Aventaggiato L: Extrarenal cytokines modulate the glomerular response to IgA immune complexes. Kidney Int 42, 341 - 353 (1992)

8 Byerley LO, Alocock NW and Starnes HF Jr: Sepsis-induced cascade of cytokine mRNA expression: correlation with metabolic changes. Am J Physiol 261, E728 - E735 (1992)

9 Fouqueray B, Philippe C, Herbelin A, Perez J, Ardaillou R and Baud L: Cytokine formation within rat glomeruli during experimental endotoxemia. J Am Soc Nephrol 3, 1783 - 1791 (1993)

10 Moriyama T, Fujibayashi M, Fujiwara Y, Kaneko T, Xia C, Imai E, Kamada T, Ando A and Ueda N: Angiotensin II stimulates interleukin-6 release from cultured mouse mesangial cells. J Am Soc Nephrol 6, 95 - 101 (1995)

11 Nakamura A, Johns EJ, Imaizumi A, Yanagawa Y and Kohsaka $\mathrm{T}$ : Effect of $\beta_{2}$-adrenoceptor activation and angiotensin II on tumour necrosis factor and interleukin- 6 genes transcription in the rat renal resident macrophage cells. Cytokine 11, $759-765$ (1999)

12 Kaneto H, Morrissey JJ, McCracken R, Ishidoya S, Reyes AA and Klahr S: The expression of mRNA for tumour necrosis factor alpha increases in the obstructed kidney of rats soon after unilateral ureteral ligation. Nephrology 2, 161 - 166 (1996)

13 Nakamura A, Iwao H, Fukui K, Kimura S, Nakanishi S and Abe $\mathrm{Y}$ : Regulation of liver angiotensinogen and kidney renin mRNA levels by angiotensin II. Am J Physiol 256, E1 - E6 (1990)

14 Foley KP, Leonard MW and Engel JD: Quantitation of RNA 
using the polymerase chain reaction. Trends Genet 9, 380-385 (1993)

15 Tanabe O, Akira S, Kamiya T, Wong GG, Hirano $\mathrm{T}$ and Kishimoto T: Genomic structure of the murine IL-6 gene: high degree conservation of potential regulatory sequences between mouse and human. J Immunol 141, 3875 - 3881 (1988)

16 Tada M, Fukamizu A, Seo M, Takahashi S and Murakami K: Nucleotide sequence of rat renin cDNA. Nucleic Acids Res 16, 3579 (1988)

17 Okubo H, Kageuyama R, Ujihara M, Hirose T, Inayama S and Nakanishi S: Cloning and sequence analysis of cDNA for rat angiotensinogen. Proc Natl Acad Sci USA 80, 2196-2200 (1983)

18 Nakamura A, Johns EJ, Imaizumi A, Yanagawa Y and Kohsaka $\mathrm{T}$ : $\beta_{2}$-Adrenoceptor agonist suppresses renal tumour necrosis factor and enhances interleukin- 6 gene expression induced by endotoxin. Nephrol Dial Transplant 24, 1121 - 1129 (2000)

19 Minami M, Kuraishi Y and Satoh M: Effect of kainic acid on messenger RNA levels of IL-1b, IL-6, TNF alpha and LIF in the rat brain. Biochem Biophys Res Commun 176, 593 - 598 (1991)

20 Nakamura A, Johns EJ, Imaizumi A, Abe T and Kohsaka T: Regulation of tumour necrosis factor and interleukin- 6 gene transcription by $\beta_{2}$-adrenoceptor in the rat astrocytes. J Neuroimmunol 88, $144-153$ (1998)

21 Nyui N, Tamura K, Yamaguchi S, Nakamura M, Ishigami T, Yabana M, Kihara M, Ochiai H, Miyazaki N, Uemura S and Ishii M: Tissue angiotensinogen gene expression induced by lipopolysaccharide in hypertensive rats. Hypertension 30, 859 867 (1997)

22 Kobori H, Harrison-Bernard LM and Navar LG: Enhancement of angiotensinogen expression in angiotensin II-dependent hypertension. Hypertension 37, 1329 - 1335 (2001)

23 Nakamura A and Johns EJ: Effect of renal nerves on expression of renin and angiotensinogen genes in rat kidneys. Am J Physiol 266, E230 - E241 (1994)

24 Iwao H, Fukui K, Kim S, Nakayama K, Ohkubo H, Nakanishi S and Abe Y: Sodium balance effects on renin, angiotensinogen, and atrial natriuretic polypeptide mRNA levels. Am J Physiol 255, E129 - E136 (1988)

25 Zhang SL, Chen X, Filep JG, Tang SS, Ingelfinger JR, Carriere $\mathrm{S}$ and Chan JS: Effect of renin-angiotensin system blockade on the expression of the angiotensinogen gene and induction of hypertrophy in rat kidney proximal tubular cells. Exp Nephrol 9, $109-117$ (2001)

26 Kobori H, Harrison-Bernard LM and Navar LG: Expression of angiotensinogen mRNA and protein in angiotensin II-dependent hypertension. J Am Soc Nephrol 12, 431 - 439 (2001)

27 Goetzl EJ, Klickstein LB, Watt KWK and Wintroub BU: The preferential human mononuclear chemotactic activity of the substituent tetrapeptides of angiotensin II. Biochem Biophys Res Commun 97, 1097 - 1102 (1980)

28 Scheidegger KJ, Butler S and Witztum JL: Angiotensin II increases macrophage-mediated modification of low density lipoprotein via a lypoxygenase-dependent pathway. J Biol Chem 272, 21609-21615 (1997)

29 Naftilan AJ, Pratt RE and Dzau VJ: Induction of platelet derived growth factor A-chain and c-myc gene expressions by angiotensin II in cultured rat vascular smooth muscle cells. J Clin Invest 83, 1419 - 1429 (1989)

30 Wolf $\mathrm{G}$ and Neilson EG: Angiotensin II as a renal cytokine. News in Physiological Sciences 9, 40 - 42 (1992)

31 Bachetti T, Comini L, Pasini E, Cargnoni A, Curello S and Ferrari R: ACE-inhibition with quinapril modulates the nitric oxide pathway in normotensive rats. J Mol Cell Cardiol 33, $395-403$ (2001)

32 Kayama E, Yoshida T, Kodama Y, Matsui T, Matheson JM and Luster MI: Pro-inflammatory cytokines and interleukin-6 in the renal response to bacterial endotoxin. Cytokine 9, $688-$ 695 (1997)

33 Hamar P, Peti-peterdi J, Razga Z, Kovacs G, Heemann U and Rosivall L: Coinihibition of immune and renin-angiotensin systems reduces the pace of glomerulosclerosis in the rat remnant kidney. J Am Soc Nephrol Suppl 10, S234-S238 (1999)

34 Schindler R, Dinarello CA and Koch K-M: Angiotensin-converting-enzyme inhibitors suppress synthesis of tumour necrosis factor and interleukin 1 by human peripheral blood mononuclear cells. Cytokine 7, 526 - 533 (1995)

35 Peeters ACTM, Netea MG, Kullberg BJ, Thien $\mathrm{T}$ and van der Meer JWM: The effect of renin-angiotensin system inhibitors on pro- and anti-inflammatory cytokine production. Immunology 94, 376 - 379 (1998) 